\title{
Reflections
}

\section{Post-politics of (Scottish) planning: gatekeepers, gatechecks and gatecrashers? - commentary to Walton}

\author{
VESA KANNINEN
}

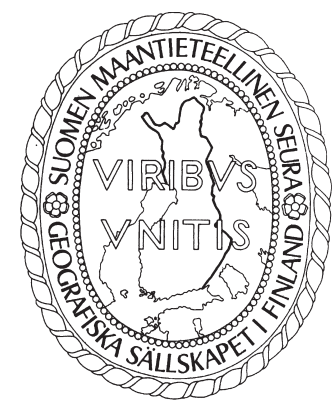

Kanninen, V. (2018) Post-politics of (Scottish) planning: gatekeepers, gatecheck and gatecrashers? - commentary to Walton. Fennia 196(1) 103107. https://doi.org/10.11143/fennia.69905

Reflecting upon William Walton's work in this issue of Fennia, this commentary elaborates on the ideas of post-politics evoked by Walton's careful examination of Scottish planning. Applying viewpoints of depoliticization and post-politics may not provide pragmatic guidance for planning practice, yet it may sensitize to and enable revelations of situational, processual and structural workings of power. With new orchestrations of planning narrowing the spaces for local resistance politicisations, depoliticisation may be taken to mean less politics. However, the complicit politicisations brought about by applying governmental technologies may also be seen as a different kind of statecraft, resulting in all too visible politics of planning presented as technicalities. This calls for local action. 'Gatecrashing' the planning system for a disruptive re-introduction of more inclusive and empowering planning practices could mean attaining 'agonistic spaces' that could enable dialectical approaches under uneven power relations.

Keywords: post-politics, agonism, Scotland, spatial planning, depoliticisation

Vesa Kanninen, Department of Built Environment, Aalto University, PO. Box 14400, 00076 Aalto, 02150 Espoo, Finland. E-mail: vesa.kanninen@aalto.fii

The main thrust of this commentary emerges from William Walton's (2018) research paper. The article is deeply rooted in the details of planning practice, and it raises important and vital contemporary concerns that are necessary to engage with for spatial planners in the Nordic region. While Scottish concerns can seem structurally distant and culturally different to those in the North East European social-democratic inspired systems we are familiar with, the issues Walton brings up touch upon timely universal issues that are well applicable to the Nordic context. It is precisely for this reason that the case of the Scottish planning landscape is an interesting one to consider here in Fennia. The article examined can be seen as a universal reminder of the systemic and situational challenges that rollback planning presents for all actors. William Walton, whose long-running research focuses upon planning and environmental law, has provided much food for thought with his insightful approach.

Having previously studied the British planning system (Bäcklund \& Kanninen 2015; Kanninen \& Akkila 2015), I draw upon this knowledge to expand upon Walton's arguments. Walton' detailed account leaves one astounded as to the depth to which differences can be traced between the Scottish planning landscape and its Finnish counterpart. Yet, in spite of glaring initial differences, the post-political lens through which Walton examines the Aberdeenshire case, a region in eastern 
Scotland, reveals much in common. Walton's article adeptly engages the reader and announces postpolitical 'optics' of a neoliberal system of governance and planning. Indeed, given the growing grip of neoliberal ethos over Europe's far north, I was inspired to further explore aspects of the post-politics Walton raises.

In my commentary, I seek to offer not an alternative but a complementary analysis of the postpolitical condition, dwelling in the empirically and theoretically grounded interpretation of planning practice that Walton's work identifies. Walton's article contains the full spectrum of post-politics played out within a single, long running, city-regional planning case. What caught my eye in the first place was the issue in itself. The perpetual questions of housing delivery, affordability, and a skirmish over locations for future development, have all the makings of a 'wicked' problem (Rittel \& Webber 1973) or, as often preferred nowadays, 'complexity' that cannot be simply dealt with by applying any existing solutions. In the end, dealing with it simply is what Walton suggests, and I think quite rightly so. Yet, to walk the intellectual path of post-politics is by no means a meager undertaking. Should one take Mouffe's and Laclau's hand, one ends up in the land of Ranciere and Žižek, pondering the pervasiveness of the political, the rarity of the truly political, the impossibility of politics within managerialistic (state) practices, and the constitutiveness of 'the other' of the political (cf. Kanninen 2017).

While these political theorists are correct to point out that the political exists as a possibility in everything, and that the post-political situation does not mean that consensus has replaced conflict, the rather hopeless place they have reached arguably does not give much hope nor power to a citizen attempting to appeal a planning case. One could point out that, in the act of carrying out legal reforms, there can always be unintended consequences, as well as 'hidden' consequences that may or may not be planned. Yet, according to the tenets of post-politics, these are nevertheless somehow 'orchestrated', as Allmendinger and Haughton (2012) phrase in their notion of how various 'governmental technologies' are being utilised for realising neo-liberal politics.

There are numerous viable theoretical accounts of power, many of which could be instrumental in analysing cases such as the one Walton identifies. In this instance, I find Hay's $(2014,299)$ critique of Wood and Flinders' (2014) three-fold typology of depoliticisation useful. Hay instead refers to Lukes' (1974) three-dimensional view of power, in parallel with Flinders and Buller's $(2006,314)$ earlier reading of Lukes' work. In Lukes' view, the first dimension concerns decision-making out in the open, reflecting the situational and actor-specific institutionalised power relations that may and do play out in conflict situations. The second dimension concerns agenda-setting power, that there is an inclination to foreground some conflicts while backgrounding others, as Schattschneider (1960, 71) famously phrased it, "organisation is the mobilisation of bias". Lukes' third dimension, in turn, shows that not all power use is active decision-making nor actively framing such situations, but rather indirect, invisible and inaudible manipulation and persuasion without noticeable conflict. In this view, the lack of conflict cannot be interpreted as consensus, as this kind of 'preference shaping' aims at naturalising the hegemonic discourse. At the strategic development plan level, the Scottish planning policy and practice exhibits the characteristics of depoliticisation in all three Lukesian dimensions of power.

The post-politics of the Aberdeenshire case evokes the approach of Foster, Kerr and Byrne (2014), in which they see depoliticisation as the return of the state, not as a "rolling back" of the state, as many authors insist. For Foster and colleagues, depoliticisation means not less, but different kind of politics. To borrow their Foucauldian vocabulary, the 'resistance politicisations' of the citizens are not really rendered useless in the face of technicalisation of issues and knowledge. They are, instead, engulfed in an all-encompassing depoliticisation together with governmental 'complicit politicisations' that serve neo-liberal government rationalities. The view of Foster and colleagues seems rather pessimistic of any real possibility of resistance, as the resistance politicisations they envision function as performances necessary for neo-liberal roll forward. It is this kind of governmentality through which post-politics are arrived at. In the case of Aberdeenshire, this is all too visible and audible. The local representatives and village residents complain to Walton as they have complained within the planning process and elsewhere, presumably in vain. Foucault sees this inability to pierce the neo-liberal armour of tech-talk as inevitable. Yet, the effort is necessary, as Thiele $(1990,916)$ describes, stating Foucault's Socratic phrase "the uncontested life is deemed not worth living". 
Meanwhile, the technicised process advances state interests through several layers. This roll forward perhaps reaches its maximum with state guidance and policies for the Reporter of a planning case. That is what the Reporter takes into account when considering a case such as the long-running, city-regional planning one considered in Walton's article. However, consider the process in which $a$ charrette, which aims at bringing forth new ideas and centres on co-creation, is subsequently labelled as a venue for politicisation. It is then argued by the Reporter that this design setting, now in the past, was the time when the concerns of locals had to be voiced and registered. Surely, such a notion by the authoritative government official makes one wonder whether one has mistaken the role of the charrette. This portrays how easily framings can be altered to suit upholding and advancing the hegemonic view.

Yet, we feel sympathetic towards the Reporter. The guidance and policies for the case Reporter, together with some unwritten or well-hidden advice, scale, scope and frame the Reporter's remit in ways quite unimaginable to the public. There is, for example, a self-regulatory aspect to the Reporter's work. As an expert, the Reporter is both part of, and affected by the government technologies that provide a web of politicisations no one can escape. There are seemingly obvious institutional, professional and ethical limitations to utilizing the full remit, empathetic as the Reporter might be to varying views. In addition, being flanked by a senior state official in public brings about institutional pressure, hence self-regulation.

We have now come to realise the ambiguity of the agency of the Reporter, within the post-politics framework that Walton so adeptly describes. Indeed, this seems to hint that there are possibilities for making changes, as the armour of this pivotal gatekeeper seems not impenetrable, after all. In my view, this refers to the inherently incomplete nature of any depoliticisation attempt, as pointed out by political theorists mentioned previously. But who actually are orchestrating, who are the orchestrated, and where are all parties drawing the line between 'us' and 'them'? If we took Walton's meta-narrative of statecraft seriously, we would probably consider the local residents, councilors, sometimes even the local planners as the antagonistic 'other' of the post-politics regime. Once this 'other' becomes aware of its common interests, as it might through such accounts as Walton's, there is a possibility of genuine resistance. As Žižek (1997) puts it, the condition of impossibility is also a condition of possibility. Truly hegemonic power is unattainable since all power relations are contingent, and the conditions that enable them are equally contingent. There are always possibilities for altering the conditions, hence also the power relations (cf. Laclau 1990).

The theoretical consolation this offers to those struggling to get heard in a planning case might not be that great. Yet, as a consequence, we need not paint a purely grim picture. As Walton's account shows, the cracks and leaks of the supposedly hegemonic practice are, in reality, well visible and often also within reach. Mouffe (2013) reminds us that if agonistic, respectful conflicts are not possible, politics will burst out in antagonistic, even violent ways. In his article, however, Walton is discussing a long-running planning case peacefully, and conversing with the other 'others' without much in way of antagonistic rebellion. I take this relative gentleness to mean that for Walton, as well as for others, there are still agonistic avenues open for exploration.

These avenues, however, might become far narrower if the newest neoliberal reforms are carried out. As Walton notes with a degree of suspicion, the notion of a "gatecheck" has been suggested. This would allow early scrutiny over a development plan evidence base. The word 'gatechecking' is appropriate and telling. The stakeholders, identified in advance, approve the evidence base for the plan before further work may commence. This would allegedly be an instrument of speeding up housing delivery, of creating efficiencies and of enabling an even lighter-touch examination process. These are laudable objectives in themselves, and a robust evidence base is certainly a pivotal asset in any planning process. However, what gatechecks may well come to mean is pre-determination of access to the planning process. The focus on evidence should not be at the expense of democracy, therefore not at the expense of meticulously upholding the openness for community dispute and politicisation. What about evidence that comes up during the planning process? What about those parties/actors/citizens who haven't been signatories? Is there any place for voicing concerns in a way that produces a dialogue? What if something changes in the demand, much as Walton's present case 
portrays? With gatechecking, does it become even more difficult to flexibly reformulate strategies, reposition development, and realign policies?

As Walton frames the case with an approach that combines post-politics with the idea of (legal) checks and balances, he points exactly at the conjuncture of Lukesian power dimensions. While there are depoliticising forces at work, some out in the open, some hidden or "elsewhere", exercising power, framing, and shaping the possibilities of resistance to unwanted development, there are also technologies which may be utilised to exercise democratic power for and by communities. As Walton explains, while there are obvious problems ahead when the 'red light' legal conjunctures are taken too far, it is equally clear that an unchecked 'green light' approach has severe repercussions, too. Therefore, the 'amber light' approach has both practical appeal and political foothold. In Finland, we remain part of a 'red light zone' system of spatial planning, but already the scarce 'amber lights' are being dimmed in favour of 'green'. Yet, we talk about improving inclusion, adding participation, and enhancing democracy.

Surely, the ideas of inclusion, participation and democratic control are not to be merely practiced as going through the motions of what is legally obligated. For anyone in a planning process, being able to exercise power does not negate moral responsibility for acting in the interests of those who planning is ultimately for, citizens. As Inch (2015) argues, it is one thing to raise 'good citizens' for deliberating within planning practices, and quite another to allow for an agonistic planning citizenship that may respectfully confront whatever is deemed inappropriate or detrimental. As Rancière (2006) notes, there is no such thing as a democratic state, and hence no such institutional solution that could truly govern democracy. Therefore, it is the citizens who should take on this sort of 'gatecrashing' attitude, respectful yet determined, in planning processes. It should be a real possibility for stakeholders and citizens at large to engage, become 'ignited' (Inch 2015) if you will. A back-and-forth of genuine dialogue addresses not only rational arguments but also the subjective, positional and situational viewpoints that are becoming more central in our relational world. Gramsci (1971), Lukes (1974) and for example Flinders and Buller (2006) provide the fundaments for gatecrashing: to go against preference-shaping depoliticisation, one should dissect whatever is considered 'natural'; to expose rule-based depoliticisation, one should question the framings of practice and process; and to kick back at institutional depoliticisation, one should enable the making of aternative decisions.

It might be that for this to happen, we need new spaces that emanate from local need through local action, spaces of the kind Bond $(2011,176)$ calls "agonistic space". Such actual spaces would provide real alternatives and possibilities to recast those alternatives towards genuinely democratic ends. In agonistic spaces, hegemonic traits could be exposed. Pratt $(1991,34)$ introduced a similar notion of a "contact zone" that could engender a space for voicing views under and about uneven power relations, under conditions Bakhtin $(1981,296)$ calls "heteroglossia", the simultaneous existence of various viewpoints. This seems not an easy concept nor one easy to operationalise, yet this is just what Walton suggests. In my opinion, to (re)introduce spaces that enable agonism is indeed a simple and workable solution to a complex problem. However, the real, radical message is this: let's talk, debate and brawl more, not less. Apart from this being a timely and valuable democratic statement, the actual practice would be an antidote for much of what seems to be going wrong with current planning systems, with their gatekeeping and gatechecking. However, to get the message through and the practice reinstated, the cracks, leaks and poorly guarded backdoors need to be utilized. The systems need to be gatecrashed!

\section{Acknowledgements}

The work on this comment has been funded by the Academy of Finland, grant 303538.

\section{References}

Allmendinger, P. \& Haughton, G. (2012) Post-political spatial planning in England: a crisis of consensus? Transactions of the Institute of British Geographers 37(1) 89-103.

https://doi.org/10.1111/j.1475-5661.2011.00468.x 
Bakhtin, M. (1981) The Dialogic Imagination. University of Texas Press, Austin.

Bond, S. (2011) Negotiating a 'democratic ethos': moving beyond the agonistic - communicative divide. Planning Theory 10(2) 161-186. https://doi.org/10.1177/1473095210383081

Bäcklund, P. \& Kanninen, V. (2015) Valtaistetut asukkaat: neighbourhood planning ja asuinalueperustaisen osallistumisen rajaamisen taktiikat. Alue ja ympäristö 44(1) 4-16. <https://aluejaymparisto.journal.fi/article/view/64830/26059>

Flinders, M. \& Buller, J. (2006) Depoliticisation: principles, tactics and tools. British Politics 1(1) 293318. https://doi.org/10.1057/palgrave.bp.4200016

Foster, E., Kerr, P. \& Byrne, C. (2014) Rolling back to roll forward: depoliticisation and the extension of government. Policy \& Politics 42(2) 225-241. https://doi.org/10.1332/030557312X655945

Gramsci, A. (1971) Selections from the Prison Notebooks. Lawrence \& Wishart, London.

Hay, C. (2014) Depoliticisation as process, governance as practice: what did the first wave get wrong and do we need a 'second wave' to put it right? Policy \& Politics 42(2) 293-311. https://doi.org/10.1332/030557314X13959960668217

Inch, A. (2015) Ordinary citizens and the political cultures of planning: in search of the subject of a new democratic ethos. Planning Theory 14(4) 404-424. https://doi.org/10.1177/1473095214536172

Kanninen, V. (2017) Strateginen kaupunkiseutu - Spatiaalinen suunnittelu radikaalina yhteensovittamisena [The strategic city region - Spatial plannig as radical coordination]. Aalto University Doctoral Dissertations 227/2017. http://urn.fi/URN:ISBN:978-952-60-7728-4

Kanninen, V. \& Akkila, I. (2015) Kaupunkiseutujen strateginen suunnittelu. Ympäristöministeriön raportteja 24/2015. Ympäristöministeriö, Helsinki. http://hdl.handle.net/10138/156626

Laclau, E. (1990) New Reflections on the Revolution of Our Time. Verso, London.

Lukes, S. (1974) Power: A Radical View. Macmillan, London. https://doi.org/10.1007/978-1-349-02248-9

Mouffe, C. (2005) On the Political. Routledge, Abington.

Mouffe, C. (2013) Agonistics: Thinking the World Politically. Verso, New York.

Pratt, M. L. (1991) Arts of the Contact Zone. Profession 91 33-40.

Rancière, J. (2006) Democracy, republic, representation. Constellations 13(3) 297-307. https://doi.org/10.1111/j.1467-8675.2006.00402.x

Rittel, H. \& Webber, M. (1973) Dilemmas in a general theory of planning. Policy Sciences 4(2) 155-169. https://doi-org.libproxy.ncl.ac.uk/10.1007/BF01405730

Schattschneider, E. E. (1960) The Semisovereign People: A Realist's View of Democracy in America. Holt, Rinehart and Winston, Chicago.

Thiele, L. (1990) The agony of politics: the Nietzschean roots of Foucault's thought. The American Political Science Review 84(3) 907-925. https://doi.org/10.2307/1962772

Walton, W. (2018) Deregulated free-for-all planning, new settlements and the spectre of abandoned building sites in Scotland's crisis-hit oil economy. Fennia 196(1) 58-76. https://doi.org/10.11143/fennia.65626

Wood, M. \& Flinders, M. (2014) Rethinking depoliticisation: beyond the governmental. Policy \& Politics 42(2) 151-170. https://doi.org/10.1332/policypress/9781447326601.003.0002

Žižek, S. (1997) The Abyss of Fear. University of Michigan Press, Ann Arbor. 